\section{PREDATION ON WOODCHUCK BY CANADA LYNX IN BRITISH COLUMBIA}

by Michael Wilson, 196 Westover Drive, Calgary 5, Alberta

In a recent paper, de Jong (1966) described the food habits of the Canada Lynx, Felis (Lynx) canadensis, in Alberta and the Northwest Territories, noting a dependence upon the Snowshoe Hare (Lepus americanus) and, to a lesser extent, upon various microtine rodents.

On the basis of this and other work (Saunders, 1966; Novikov, 1962; Cowan and Guiguet, 1955) it is probable that the Snowshoe Hare is of similar importance as a prey species in British Columbia.

The present paper brings attention to a Lynx skeleton (U. of Calgary, Archaeology Collections, no. OS-268) collected in 1967 by Mr. C. J. Turnbull, Dept. of Archaeology, U. of Calgary. The skeleton, from near Babine, British Columbia, was already clean when found; however, bones derived from the animal's last meal were preserved in the stomach region. They are referred without question to the genus Marmota, species undetermined.

The marmot and woodchuck were not noted as prey species by de Jong (1966), although $M$. caligata and $M$. monax are quite common in Alberta. It is difficult to assess this single record, but these rodents may be of considerable importance to the Lynx, especially in times of Snowshoe Hare scarcity. Marmota monax, the parkland species, is the only one recorded by Cowan and Guiguet (1955) at Babine Lake, but the range of $M$. caligata, a rocky slope denizen, is not far to the east. On this basis, the remains are provisionally referred to M. monax, the Woodchuck.

\section{LITERATURE CITED}

Cowan, I. McT., and C. J. Guiguet. 1955. The mammals of British Columbia. B.C. Provincial Museum, Handbook 11.

de Jong, C. G. van Z. 1966. Food habits of the Lynx in Alberta and the Mackenzie District, N.W.T. Canadian Field-Naturalist, $80: 18-23$.

Novikov, G. A. 1956. Carnivorous mammals of the fauna of the U.S.S.R. Zoological Institute of the Academy of Science of the U.S.S.R (Israel program for scientific translations, Jerusalem).
Saunders, J. K., Jr. 1963. Food habits of the Lynx in Newfoundland. Journal of Wildlife Management, 27 (3): 384-390.

\section{A STRIPED GROUND SQUIRREL LOCALITY IN SOUTHERN ALBERTA}

by Michael Wilson, 196 Westover Drive, Calgary 5, Alberta

Soper (Mammals of Alberta, 1964: 139-140) summarized the range of the Striped or Thirteen-lined Ground Squirrel (Spermophilus tridecemlineatus) in Alberta; however, the local aspects of the southern portion of this range remain poorly defined. Soper described the southern foothills range of S. $t$. tridecemlineatus (Mitchell) as follows: "... chiefly the aspen grove belt ... . west to a line running northsouth through Westlock ... to at least Missing Link Mountain and Sheep River, 10 miles southwest of Turner Valley ...."

During May and June, 1968, eight sightings of these rodents were made near Stavely, Alberta, and limited behavioural notes were taken. The sightings fall into an oval area defined in the north by Sec. 16-14-28 W4, and in the south by Sec. 25-13-28 W4, and split into east and west halves by the valley of Willow Creek. The area is characterized primarily as prairielevel river bluffs, with a few higher buttes in the north. All of the sightings were made at prairie level or higher, with an altitudinal range of 3400 to 3900 feet above sea level, and in open shortgrass to prairie of the Transition Zone (sub-humid), as defined by Soper.

Despite a tendency to be silent, two individuals observed on Table Butte (3900' above sea level) were very bold, allowing photography from less than 10 feet when they were at their burrow entrances. Away from their burrows they allowed approach only to about 25 feet. The sightings were all made on sunny days, usually warm. A sighting on May 13, 1968 was made in sunshine after a sharp shower, and one on June 20 was made in a high wind (about 40 m.p.h.) atop Table Butte. 